DOI:10.17951/h.2018.52.2.17-30

\begin{tabular}{lcc}
\hline & A N N A L E S \\
UNIVERSITATIS MARIAE CURIE-SKŁODOWSKA \\
LUBLIN - POLONIA \\
SOL. LII, 2 & SECTIOH \\
\hline
\end{tabular}

Uniwersytet Warszawski. Wydział Zarządzania

WITOLD CHMIELARZ, TOMASZ PARYS

witold@chmielarz.eu, tomasz.parys@uw.edu.pl

Wykorzystanie technologii mobilnych $w$ handlu elektronicznym

The Use of Mobile Technologies in e-Commerce

Słowa kluczowe: technologie mobilne; handel elektroniczny; m-commerce

Keywords: mobile technologies; e-commerce; m-commerce

Kod JEL: L81; M15; 033

\title{
Wstęp
}

Zasadniczym celem niniejszych badań jest analiza porównawcza uwarunkowań dokonywania zakupów za pomocą urządzeń mobilnych (smartfony, tablety), zarówno za pomocą oprogramowania aplikacji mobilnych, jak i przeglądarek internetowych, oraz porównanie z zakupami prowadzonymi przy pomocy urządzeń tradycyjnych za pomocą przeglądarek internetowych. Sfery, w której zakupy są dokonywane poprzez przeglądarki internetowe, nie ograniczono do komputerów przenośnych (PC) i stacjonarnych, ale rozszerzono ją na urządzenia mobilne. Jak wynika z poprzednich badań [Chmielarz, 2015, s. 1085-1094], użytkownicy urządzeń mobilnych często nie mają świadomości, że zakupów internetowych mogą dokonywać i przez aplikacje mobilne, i za pomocą przeglądarek ze względu na fakt, że ich wspólną infrastrukturą jest internet. Przedmiotem niniejszych badań są więc z jednej strony użytkownicy urządzeń służących do zakupów online, a z drugiej - oprogramowanie, które im to zapewnia.

Internetowy handel mobilny (m-commerce) powinien być rozumiany nie tylko jako handel realizowany za pomocą urządzeń mobilnych, ale również aplikacji 
mobilnych dostępnych na te urządzenia. Na tym głównie polega jego specyfika i odrębność [Chmielarz, Łuczak, 2016, s. 523-538]. Dokonywanie transakcji na urządzeniach mobilnych poprzez przeglądarki internetowe różni się jedynie gorszą jakością techniczną od tej dokonywanej na urządzeniach stacjonarnych. Stąd wynikają zapewne także różnice w ocenie przez użytkowników. Tym niemniej samo posiadanie urządzenia mobilnego nie świadczy o tym, że prowadzony jest za jego pomocą handel mobilny. Jest to jeszcze kwestia aktywności użytkownika, wyrażona jego znajomością aplikacji służących do zakupów i chęci ich częstego używania [Chmielarz (red.), 2016].

Urządzenia mobilne (z rosnącą dominacją smartfonów) są obecnie dla wielu ludzi na całym świecie najważniejszymi narzędziami zapewniającymi dostęp do wielu informacji i rozrywki, nie tylko kiedykolwiek, ale także (jeżeli nie przede wszystkim) gdziekolwiek znajduje się użytkownik. Globalne trendy pozwalają przewidywać też stały wzrost liczby użytkowników urządzeń mobilnych. W 2018 r. ma to być ponad 2,56 mld osób, czyli więcej niż 1/3 globalnej populacji. Wówczas odsetek użytkowników telefonów komórkowych posiadających smartfony ma, po raz pierwszy w historii, przekroczyć barierę 50\%. Do 2019 r. ich liczba ma osiągnąć 5,2 mld [Parys, 2016a, s. 13-25]. Mówiąc o rynku urządzeń mobilnych, należy pamiętać, że z roku na rok coraz bardziej się on nasyca. Powoduje to, że spada zainteresowanie zakupem nowych urządzeń. W Polsce $40 \%$ konsumentów zamierza kupić nowy smartfon, a 20\% myśli o wymianie tabletu [Szewczyk, 2016].

Rynek zakupów elektronicznych także intensywnie się rozwija za sprawą urządzeń mobilnych i tradycyjnych. W USA liczba uczestników rynku elektronicznego ma wzrosnąć z $211 \mathrm{mln}$ w 2016 r. do $224 \mathrm{mln}$ w 2019 r., chociaż tylko 1/3 sprzedaży (35\%) jest napędzana przez branżę mobilną [Number of digital shoppers...]. Wielka Brytania po raz pierwszy znajduje się w sytuacji, gdy liczba dokonywanych transakcji mobilnych prawie zrównała się z liczbą transakcji realizowanych za pomocą laptopa czy urządzeń stacjonarnych. W pierwszym kwartale 2016 r. sprzedaż online za pomocą urządzeń przenośnych uzyskała $50 \%$ wskazań na tle wszystkich transakcji online ${ }^{1}$. Oznacza to 4-procentowy wzrost w porównaniu do 2015 r. (sprzedaż mobilna wyniosła wtedy $46 \%$ wszystkich transakcji online) $)^{2}$. Rynek ten obecnie przesuwa się z USA i Europy na rynki dalekowschodnie. W najbliższych latach będzie on coraz silniej napędzany przez takie kraje, jak Chiny, Indie czy Brazylia, których mieszkańcy kupują coraz więcej smartfonów, a więc zapewne częściej będą korzystać z zakupów w internecie.

Polski handel mobilny rozwija się w trzykrotnie szybszym tempie niż e-commerce. Do 2016 r. wydatki mobilne w Polsce wzrosną do prawie 3,5 mld zł. Ewolucja rynku

1 www.criteo.com/media/3748/criteo-state-of-mobile-commerce-q4-2015-ppt.pdf [dostęp: wrzesień 2016].

2 www.ons.gov.uk/businessindustryandtrade/retailindustry/bulletins/retailsales/aug2016 [dostęp: styczeń 2017]. 
online jest wspierana przez coraz większą liczbę stron internetowych, które stanowią najpopularniejsze medium dla e-zakupów. W ciągu ostatnich 12 miesięcy 69\% polskich kupujących przez smartfony kupowało online, posługując się przeglądarką, a tylko 35\% - aplikacją [Handel mobilny w Polsce..., 2015]. Jest to zatem sfera warta prowadzenia biznesu, godna uwagi oraz wymagająca ciągłych badań.

\section{Metodyka badawcza}

W tak dynamicznym i złożonym środowisku rynkowym, jakie stwarza handel elektroniczny, oraz w warunkach wysokiej innowacyjności i konkurencyjności rozwiązań, przy rosnącej jakości oprogramowania zarówno aplikacji mobilnych, jak i systemów przeglądarkowych, nasuwają się następujące pytania:

1. Jakie są podobieństwa i różnice pomiędzy zakupami prowadzonymi przy pomocy aplikacji mobilnych i przeglądarek internetowych?

2. Jak się one mają do prowadzenia zakupów przy pomocy przeglądarek internetowych na urządzeniach tradycyjnych?

3. Jakie preferencje sposobu płatności wykazują klienci używający aplikacji mobilnych i/lub przeglądarek internetowych na obu typach urządzeń?

Odpowiedzi na te pytania może przynieść gruntowna analiza zachowań użytkowników urządzeń mobilnych i tradycyjnych oraz sposobu dokonywania przez nich zakupów przez internet. Przeprowadzono więc badania ilościowe i jakościowe użytkowników ze względu na wykorzystanie różnego typu urządzeń i aplikacji mobilnych oraz systemów przeglądarkowych. Ze względu na nieliczne i wyrywkowe badania dotyczące tej sfery, zaprezentowane zarówno w literaturze krajowej [Ziemba (red.), 2008; Wielki, 2012], jak i zagranicznej [Nielsen, 2014], oparto się na własnym podejściu składającym się z poniższych etapów:

- wybór i uzasadnienie próby badawczej użytkowników smartfonów, tabletów, laptopów oraz komputerów stacjonarnych,

- skonstruowanie ankiety na temat użytkowania i wykorzystania urządzeń mobilnych i stacjonarnych oraz oprogramowania aplikacji mobilnych i systemów przeglądarkowych w zakupach internetowych, a także umieszczenie jej na serwerach Wydziału Zarządzania Uniwersytetu Warszawskiego,

- przeprowadzenie badań, opracowanie ich i dyskusja wyników (ilościowych i strukturalnych) oraz sporządzenie na tej podstawie listy kryteriów oceny sklepów internetowych z aplikacjami mobilnymi,

- analiza i dyskusja wyników oraz konsekwencje wynikające z badań.

Badania zostały przeprowadzone w końcu grudnia 2016 r. na próbce badawczej przekraczającej 300 osób. Ankieta została rozprowadzona w formie internetowej (poprzez specjalistyczne oprogramowanie zainstalowane na serwerach Wydziału Zarządzania UW) oraz w sposób ręczny w grudniu 2016 r. Grupa badawcza należała do kategorii wygodnych - były to wybrane grupy studenckie z dwóch uczelni: 
Uniwersytetu Warszawskiego oraz Akademii Finansów i Biznesu Vistula, ze studiów licencjackich, inżynierskich i magisterskich. Na dobór grupy badawczej zdecydowano się po analizie badań D. Batorskiego [2015], który wskazał na najwyższy procent wykorzystania urządzeń mobilnych wśród grup wiekowych 16-24 i 25-34 lata (prawie 70\%), oraz danych newmarketing.pl [Handel mobilny w Polsce..., 2015], z których wynika, że 59\% kupujących przez urządzenia mobilne w 2016 r. było w wieku 18-34 lata ${ }^{3}$ (stanowili jednocześnie 34\% wszystkich nabywców online). Przyjęte założenie o wieku klientów było zarazem zaletą wyboru grupy badawczej (największy procent wykorzystania urządzeń elektronicznych i dokonywanych przy ich pomocy zakupów) oraz swoistym ograniczeniem zmniejszającym potencjalne możliwości uogólnień.

Ankietę wypełniło 449 osób, z tego 335 w sposób pełny, co stanowi 74,61\% zwrotności ankiety. Wśród nich było 75,82\% kobiet i $24,18 \%$ mężczyzn, co jest typową relacją na wydziałach o profilu ekonomicznym. W środowisku, w którym przeprowadzono badanie, prawie wszystkie osoby $(98,51 \%)$ były z grupy wiekowej 18-25 lat, a z grupy 26-30 lat niecałe 1,5\%. Według raportu POLSKA.JEST.MOBI [2015] w grupie wiekowej 20-29 lat odsetek osób posiadających smartfony wynosi $88 \%$. Respondenci przedstawionego w niniejszym opracowaniu badania autorskiego należeli w zdecydowanej większości do tej właśnie grupy wiekowej, co potwierdza prawidłowość doboru próby. W związku z powyższym struktura wykształcenia jest dostosowana do struktury wiekowej i kształceniowej: $87,76 \%$ respondentów posiada wykształcenie średnie, a 11,04\% wykształcenie licencjackie lub inżynierskie. 41,79\% ankietowanych deklarowało pochodzenie z miasta o liczbie mieszkańców od 100 tys. do ponad 500 tys., ponad $15 \%$ - z miast 50-100 tys. mieszkańców, ponad 27,16\% z miast poniżej 50 tys. mieszkańców, a $15,82 \%$ pochodzi ze wsi.

Każdy z ankietowanych udzielał subiektywnie odpowiedzi na poszczególne pytania. Oceny były następnie sumowane, dokonywana była ich strukturyzacja oraz ocena bezwzględna i wskaźnikowa. Prostota dokonywanych ocen sprawia, że respondenci popełniają stosunkowo mało błędów i uczestniczą w takich ankietach chętniej niż w ankietach dostosowanych do innych rodzajów metod. Najczęściej popełnianym błędem jest niekończenie ankiety lub brak komentarzy. Stosunkowo łatwa jest także interpretacja uzyskanych wyników.

\section{Analiza uzyskanych wyników}

Ankieta składała się z 26 pytań merytorycznych oraz 5 pytań charakteryzujących próbę badawczą. Pierwszą część stanowiły trzy wprowadzające pytania infrastrukturalne dotyczące: kwestii częstotliwości łączenia się z internetem, rodzajów używanych do tego celu urządzeń oraz częstotliwości zakupów za pośrednictwem sieci.

\footnotetext{
3 Takie same wielkości zob. [Polski handel mobilny rozwija się szybciej ..., 2015].
} 
Grupa respondentów, do której zwróciliśmy się z pytaniami, w 96\% codziennie korzysta z internetu, a 1\%, jak to określono - „cały czas”. Tylko 3\% deklaruje, że mniej niż raz dziennie, parę razy w miesiącu oraz bardzo rzadko. Zauważyć należy, iż uzyskane w niniejszym badaniu wyniki są zbliżone do uzyskanych we wcześniejszych badaniach (z czerwca 2015 r.) jednego z autorów, w którym także zdecydowana większość respondentów (98\%) wskazała częstotliwość korzystania z internetu jako „codziennie” [Parys, 2016b, s. 142-154]. Podobne wyniki uzyskano również w innym badaniu przeprowadzonym przez autorów w 2016 r., w którym na pytanie dotyczące częstotliwości korzystania z internetu 97,38\% respondentów odpowiedziało, że korzysta z niego kilka razy dziennie, a 1,31\% określiło częstotliwość jako „nieustannie” [Chmielarz, Parys, 2017]. Biorąc to pod uwagę, można uznać, że próba badawcza była złożona $\mathrm{z}$ aktywnych użytkowników internetu, dobrze znających specyfikę zjawiska, wyrażających swoje opinie w oparciu o doświadczenia wynikające z praktycznego doświadczenia w korzystaniu z tego medium.

Do kontaktów z internetem ankietowani używają głównie smartfonu (45,37\%) lub - zamiennie - smartfonu i laptopa (26,57\%). Tylko 14,63\% respondentów wykorzystuje do tego celu głównie laptopa. Wśród pozostałych 13,63\% dominuje użycie komputera stacjonarnego (3,58\%) oraz zestawu składającego się z komputera stacjonarnego, tabletu i smartfonu (3,58\%). Smartfon umocnił więc swoją pozycję, w stosunku do roku ubiegłego, o ponad 5 p.p. jako najczęściej stosowane urządzenie pozwalające nawiązać łączność z internetem. Smartfon jest urządzeniem, które zaczyna dominować $\mathrm{w}$ roli podstawowego narzędzia do korzystania $\mathrm{z}$ internetu. Potwierdzają to badania przeprowadzone przez jednego z autorów w ubiegłym roku. W badaniu tym używanie tylko smartfonu zadeklarowało $60 \%$ respondentów, smartfonu $z$ tabletem $-32 \%$, zaś smartfonu $z$ telefonem - $2 \%$ [Parys, 2016c, s. 17-27].

Dość jednoznacznie zadeklarowano się również w odpowiedzi na pytanie o częstotliwość dokonywanych zakupów. Otóż 55,82\% ankietowanych dokonuje zakupów przez internet przynajmniej raz w tygodniu i kilka razy w miesiącu, natomiast $41,79 \%$ badanych czyni to rzadko lub bardzo rzadko. Opcje „,nie mniej niż raz dziennie” zaznaczyło $1,80 \%$ respondentów, a ,nie korzystam” $-0,6 \%$, zatem stanowią one jedynie margines zachowań klienckich. W tej swoistej dwubiegunowości pocieszające są dwa fakty. Jeden dotyczy tego, że tylko ułamek procenta ankietowanej grupy nie korzysta z zakupów przez internet, natomiast drugi, że w sumie prawie $58 \%$ badanych robi zakupy w internecie nie mniej niż kilka razy w miesiącu. To świadczy o fakcie, że grupa badawcza została dobrze dobrana pod kątem możliwości zadania pytań na temat handlu mobilnego jako elementu handlu elektronicznego.

Druga część ankiety dotyczyła bezpośrednich relacji ilościowych w zakresie wykorzystania handlu mobilnego w stosunku do handlu tradycyjnego (przeglądarkowego).

Respondenci w ciągu ostatnich trzech miesięcy podczas dokonywania zakupów w 91\% wykorzystywali przeglądarkę internetową, a tylko w pozostałych $9 \%$ - aplikację mobilną. Jest to sprzeczne z obiegową opinią o ilościowej przewadze aplikacji mobilnych nad tradycyjnymi zakupami przez przeglądarki internetowe. Istotne jest tu 
pytanie, dlaczego tak się dzieje. Czy jest to sprawa gorszej jakości oprogramowania, mniejszej wygody? Czy też aplikacje mobilne wykorzystywane są tylko do działań bieżących, komunikacji i rozrywki?

Zdecydowana większość ankietowanych (ponad 62,39\%) twierdzi, że obie formy sprzedaży są porównywalne i powinny być jednakowo udostępniane na urządzeniach mobilnych, a $28,06 \%$ uważa, że sprzedaż czy usługi realizowane przez aplikacje mobilne nie są lepsze od tych wykonywanych w tradycyjny sposób przez przeglądarki internetowe. Jedynie niecałe $10 \%$ badanych podkreśla, że jest to lepszy sposób prowadzenia handlu elektronicznego.

Cechą decydującą o potencjalnej przewadze sprzedaży przez aplikacje mobilne może być powszechna dostępność urządzeń, na których są instalowane. Tak twierdzi ponad $47 \%$ respondentów. Nieco mniej istotne $(28,06 \%)$ wydaje się być przyzwyczajenie do obsługi urządzenia mobilnego, co wynika często raczej z funkcji komunikacyjnych i informacyjnych niż zakupowych oraz (często nie jest to brane pod uwagę podczas konstruowania narzędzi przeglądarkowych) z łatwości obsługi (20,30\%). Najmniej istotna, budząca jednak zdziwienie w tej grupie użytkowników, jest względna taniość usługi $(2,99 \%)$ oraz marginalnie brane pod uwagę i wymieniane przez użytkowników przyczyny, takie jak: preferencje użytkownika, ułatwienie dostępu poprzez brak konieczności każdorazowego logowania, większa mobilność, większa wiarygodność.

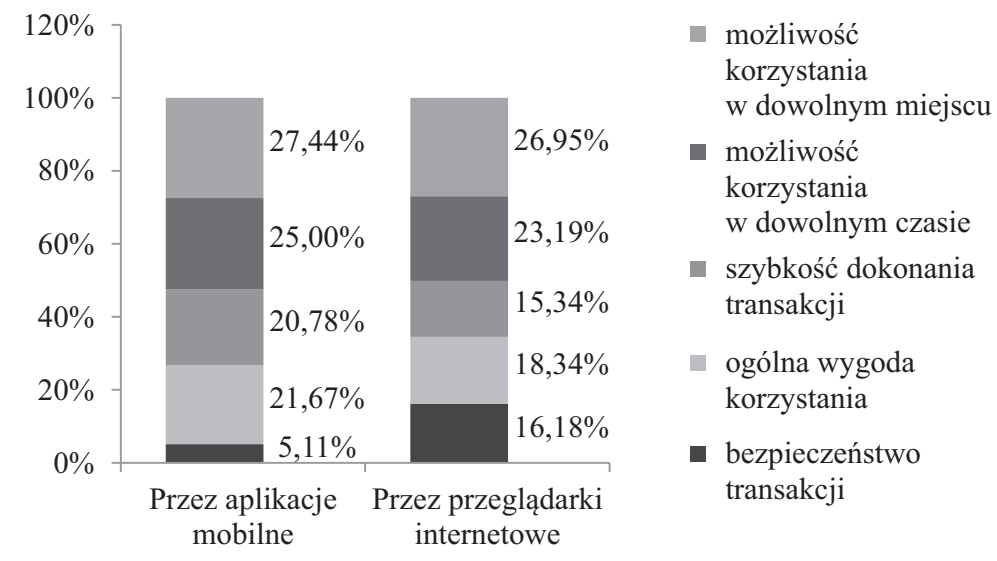

Rys. 1. Kluczowe determinanty zakupów przez aplikacje mobilne oraz przez przeglądarki internetowe na urządzeniach mobilnych

Źródło: opracowanie własne.

Użytkownicy zapytani wprost o kluczowe determinanty zakupów przez aplikacje mobilne na urządzeniach mobilnych na pierwszym miejscu $(27,44 \%)$ wymieniają możliwość korzystania z zakupów w dowolnym miejscu. Niewiele (o 2,44\%) ustępuje temu możliwość korzystania z zakupów w dowolnym czasie. Nie mniej poważnie traktowane są również ogólna wygoda korzystania z urządzenia, na którym są zain- 
stalowane (21,67\%), oraz szybkość dokonania transakcji (20,78\%). Najmniej istotne dla ankietowanych nadal pozostaje bezpieczeństwo transakcji $(5,11 \%)$. Respondenci pytani o kluczowe determinanty zakupów przez przeglądarki internetowe na urządzeniach mobilnych, najbardziej różnicują swoje odpowiedzi w zakresie bezpieczeństwa transakcji - uważają, że jego znaczenie jest ponad trzykrotnie wyższe, natomiast mniejsze znaczenie przywiązują do ogólnej wygody korzystania (o ponad 3\%) i szybkości dokonywania transakcji (o ponad 5\%). Ilustracją tych relacji jest rys. 1 .

Do oceny determinant zakupu przez przeglądarki internetowe na urządzeniach typu laptop/komputer stacjonarny zastosowano sugerowany przez respondentów zestaw kryteriów. Podstawowym czynnikiem wpływającym na używanie urządzeń tradycyjnych zgodnie z uzyskanymi wynikami jest możliwość skupienia się na transakcji i jej przemyślenia $(25,38 \%)$. Nie bez znaczenia, choć w mniejszym stopniu niż dla urządzeń mobilnych, jest też ogólna wygoda korzystania (19,33\%). Na podobnym poziomie $(18,68 \%)$ znajduje się bezpieczeństwo transakcji operacji dokonywanych na urządzeniach typu smartfon/tablet oraz typu laptop/komputer stacjonarny. Ponadto ankietowani zwrócili uwagę na takie czynniki, jak: możliwość konsultacji z bliskimi $(11,34 \%)$, mniejsze ryzyko niepotrzebnie zrobionych zakupów (12,20\%). Mniejsze znaczenie miała szybkość dokonywania transakcji oraz możliwość dokonywania jej w dowolnym czasie (rys. 2).
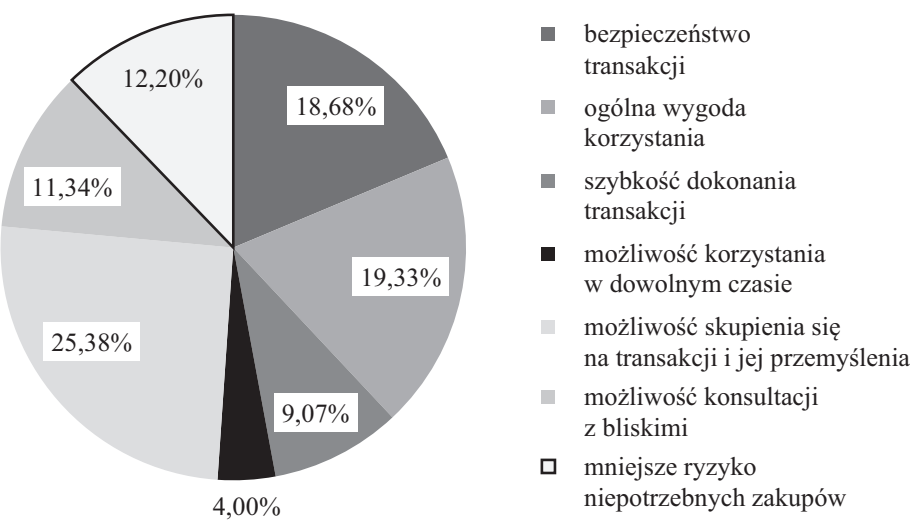

Rys. 2. Kluczowe determinanty zakupów przez przeglądarki internetowe na urządzeniach tradycyjnych (laptop/komputer stacjonarny)

Źródło: opracowanie własne.

Pytanie o większą satysfakcję z dokonywania zakupów za pomocą urządzeń tradycyjnych (laptop/komputer stacjonarny) i mobilnych przyniosło 65,37\% odpowiedzi popierających urządzenia tradycyjne, a tylko 9,25\% - urządzenia nowoczesne. $24,48 \%$ respondentów uważa, że są tak samo zadowoleni z robienia zakupów przy pomocy obu rodzajów urządzeń. Niecały $1 \%$ nie akceptuje w pełni żadnej z tych form transakcji. 
Trzecia część ankiety dotyczyła różnic pomiędzy zakupami przez aplikacje mobilne i przeglądarki internetowe. Prawie $68 \%$ respondentów twierdzi, że oba rodzaje zakupów znacząco się różnią, a jedynie $12 \%$ uważa, że różnice te nie są aż tak istotne. Ponad $20 \%$ ankietowanych nie ma na ten temat żadnego zdania. Jednym z wyróżników zauważonych różnic są przyczyny braku satysfakcji z posługiwania się podczas zakupów urządzeniami mobilnymi i urządzeniami tradycyjnymi.

Podczas wykorzystywania aplikacji mobilnych na urządzeniach mobilnych największą przeszkodą w dokonywaniu zakupów jest mniejsza czytelność komunikatów (36,12\%) oraz konieczność dłuższego przewijania ekranów (27,46\%). Mniej istotna jest większa procentowo zajętość ekranu urządzenia mobilnego niż na urządzeniu tradycyjnym oraz bezpieczeństwo transakcji (rys. 3).

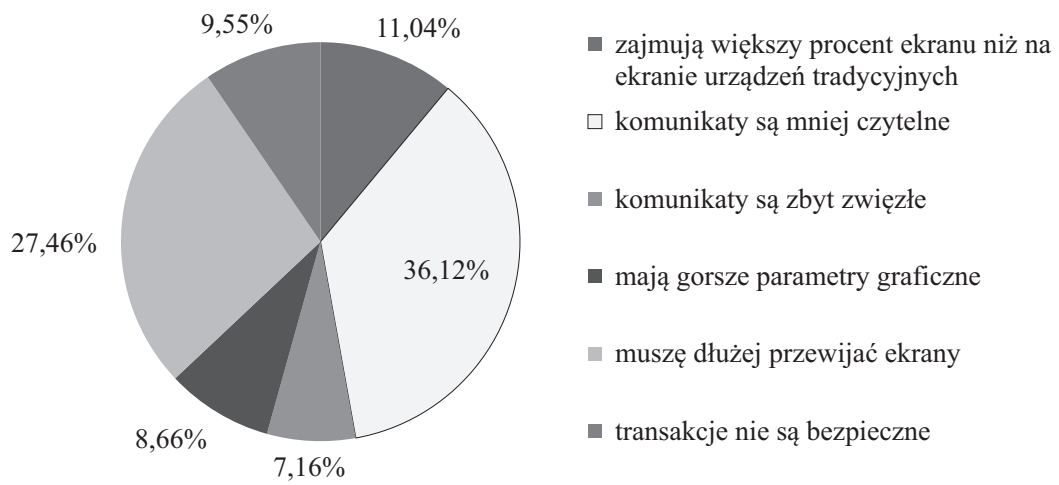

Rys. 3. Główne wady wykorzystania aplikacji mobilnych w urządzeniach mobilnych w handlu elektronicznym

Źródło: opracowanie własne.

Wady wykorzystania przeglądarek internetowych do zakupów w urządzeniach tradycyjnych według ankietowanych polegają głównie na nadmiarze wyświetlających się reklam $(57,11 \%)$ oraz długiej drodze realizacji opcji zakupowych i nadmiernej ilości propozycji zakupu (w sumie 29,26\%). Nisko oceniana jest wygoda transakcji (ponad 10\%), ale i tak wyżej niż w używanych do tego samego celu urządzeniach mobilnych. Najmniej przeszkadza niepewność bezpieczeństwa transakcji (3,58\%).

Wady wykorzystania przeglądarek internetowych w urządzeniach mobilnych zasadniczo różnią się od poprzednich. Za największą wadę została uznana długa droga dotarcia do opcji zakupowych. Co prawda, relatywne zmniejszenie ilości wyświetlanego tekstu i uproszczenie działania (a nawet niekiedy funkcjonalności) przeciwdziała tej opinii, ale być może nie wszyscy, nawet aktywni, internauci o tym wiedzą. Lepiej oceniany jest marketing - z powodu relatywnie mniejszego ekranu i nie do końca rozpoznanych uwarunkowań rzeczywiście jest on mniej nachalny w urządzeniach mobilnych niż w urządzeniach tradycyjnych. Podobne uwagi można skierować do ilości opcji zakupowych - wymuszone dostępnym miejscem 
zmniejszenie tekstu powoduje też zmniejszenie odczucia (co nie jest często zgodne z rzeczywiście prezentowaną ilością produktów) nadmiarowości oferty.

Co jest $\mathrm{w}$ takim razie główną zachętą do korzystania $\mathrm{z}$ aplikacji mobilnych W zakupach internetowych? W odpowiedzi na to pytanie respondenci podzielili się na trzy niemal równoważne grupy. Wśród nich znaleźli się ci, co uważają, że najważniejszą zachętą jest:

- mniejsza nachalność marketingu niż w handlu przeglądarkowym (38,81\%),

- zawartość treści ograniczona do minimum $(31,04 \%)$,

- większa wygoda korzystania niż w handlu przeglądarkowym (30,15\%).

Zastanawia powtarzająca się w odpowiedziach na kolejne pytania zawarte w tej ankiecie, jak również uzyskana $\mathrm{w}$ innych badaniach, niechęć do form prowadzenia marketingu internetowego.

W tym kontekście za najważniejsze cechy skłaniające do zakupów poprzez aplikacje mobilne w urządzeniach mobilnych uznano w 43,57\% wszechobecność (zawsze i wszędzie) dostępu. Dziwi trochę fakt, że nadal, po trzech latach ekspansywnego rozwoju, są uważane przez znaczącą liczbę respondentów (prawie 24\%) za wskaźnik nowoczesności firmy, która je stosuje. Niemniej istotna (prawie 20\%) okazuje się łatwa, dynamiczna i elastyczna interakcja z odbiorcą. Najmniej wagi przywiązują ankietowani do spersonalizowanego przekazu oraz bardziej osobistego kontaktu (w sumie 12,86\%) tych aplikacji (rys. 4).

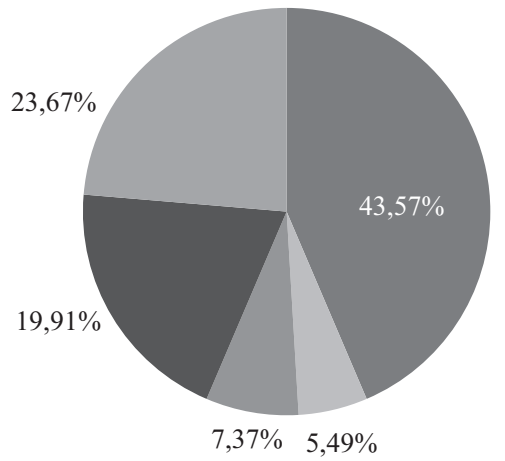

Rys. 4. Zalety zakupów przez aplikacje mobilne
- są zawsze i wszędzie dostępne

są bardziej osobiste

- występuje spersonalizowany przekaz

- występuje łatwa, dynamiczna i elastyczna interakcja z odbiorcą

- stanowią wskaźnik nowoczesności firmy, która je stosuje

Źródło: opracowanie własne.

W ankiecie zainteresowano się również próbami zwiększenia oddziaływania na intencje zakupowe poprzez instalację show-roomu. Ideą tego pomysłu było od początku zwiększenie siły oddziaływania handlu elektronicznego poza dwa podstawowe, jak dotąd, zmysły, dzięki którym klient odbiera przekaz internetowy, czyli wzroku i słuchu. W show-roomie może dodatkowo dotknąć serwowany towar (zmysł dotyku), powąchać (o ile to istotne dla zakupu - zmysł powonienia), a nawet polizać próbki (zmysł smaku). Z drugiej strony wymaga to, niestety, przemieszczenia się do 
miejsca, w którym się taki punkt znajduje, a to kojarzy się z zakupami tradycyjnymi w sklepie, takimi, gdzie pierwsze informacje o towarze czy usłudze uzyskujemy dzięki internetowi, ale decydujemy się kupować w świecie realnym. Nie powinny więc chyba dziwić wyniki tego zapytania, z których wynika, że ponad 34\% ankietowanych nie wie, jakie może być znaczenie tego typu rozwiązań dla handlu elektronicznego realizowanego na urządzeniach mobilnych i tradycyjnych. Co prawda, równie wielu respondentów przyznaje im albo takie samo znaczenie, albo jednej lub drugiej formie handlu elektronicznego po $14-17 \%$, ale to, jak się wydaje, nadal nie świadczy ani o znajomości, ani o popularności tej idei.

Czwarta część ankiety była przeznaczona do analizy funkcji i obszarów (branż) zastosowań handlu elektronicznego w postaci mobilnej i tradycyjnej poprzez przeglądarki i aplikacje mobilne.

Na początku zajęto się przede wszystkim takimi funkcjonalnościami aplikacji mobilnych i przeglądarek internetowych, które przeważają podczas wykorzystania ich w handlu elektronicznym. W aplikacjach mobilnych podkreśla się korzystanie w przeważającej części $(45,07 \%)$ z funkcji zakupowych, które w systemach przeglądarkowych za najważniejsze uważa niecałe $30 \%$ respondentów. Sytuacja odwrotna występuje w funkcjach informacyjnych, gdzie w aplikacjach mobilnych uważa je za najważniejsze $31 \%$ ankietowanych, a w systemach przeglądarkowych - ponad $42 \%$. Świadczy to o fakcie częstszego używania systemów przeglądarkowych tylko w celu zasięgnięcia informacji o cechach produktu i ewentualnie o jego cenie w zależności od sklepu, w którym dany towar/usługa występuje. Istotna jest również możliwość dokonania płatności, na którą w systemie tradycyjnym wskazuje aż 20,30\% ankietowanych, tj. o blisko 7 p.p. mniej podczas używania aplikacji mobilnych. Ostatnią pozycję zajmują funkcje pośredniczące (np. aukcje), które w obu przypadkach są wskazywane przez około $10 \%$ respondentów.

W ciągu ostatnich trzech miesięcy przed wypełnieniem ankiety respondenci kupowali najczęściej bilety komunikacji (średnio 28\%), odzież i obuwie (średnio $18 \%$ ), książki, filmy, muzykę (średnio 15\%), kosmetyki (średnio 13\%) i bilety na imprezy (kino, teatr, mecz, wydarzenia - 12\%). W zależności od wykorzystywanych urządzeń wystąpiły jednak pewne różnice w zakupach poszczególnych rodzajów produktów. Przez urząadzenia mobilne przede wszystkim (38,51\%) kupowano bilety (autobusowe, kolejowe, lotnicze), następne w kolejności są odzież i obuwie, które kupowało blisko trzykrotnie mniej respondentów (14,03\%). Najmniej, w ostatnim czasie, przez urząazenia mobilne kupowano wyjazdów turystycznych $(0,90 \%)$ oraz urządzeń AGD (1,79\%). Rozrzut pomiędzy najczęściej kupowanymi produktami a tymi kupowanymi najrzadziej wynosi ponad 37 p.p. Przez urządzenia tradycyjne najwięcej kupowano odzieży i obuwia $(21,75 \%)$ oraz biletów komunikacyjnych (16,79\%). Powyżej średniej $(11,11 \%)$ znalazły się również zakupy książek, filmów, muzyki, kosmetyków i biletów na imprezy. Najmniej osób kupiło gry komputerowe (4,01\%). Rozrzut pomiędzy najmniejszą i największą wartością wynosił mniej niż 18 p.p., czyli dwukrotnie mniej niż w przypadku urządzeń mobilnych (rys. 5). 


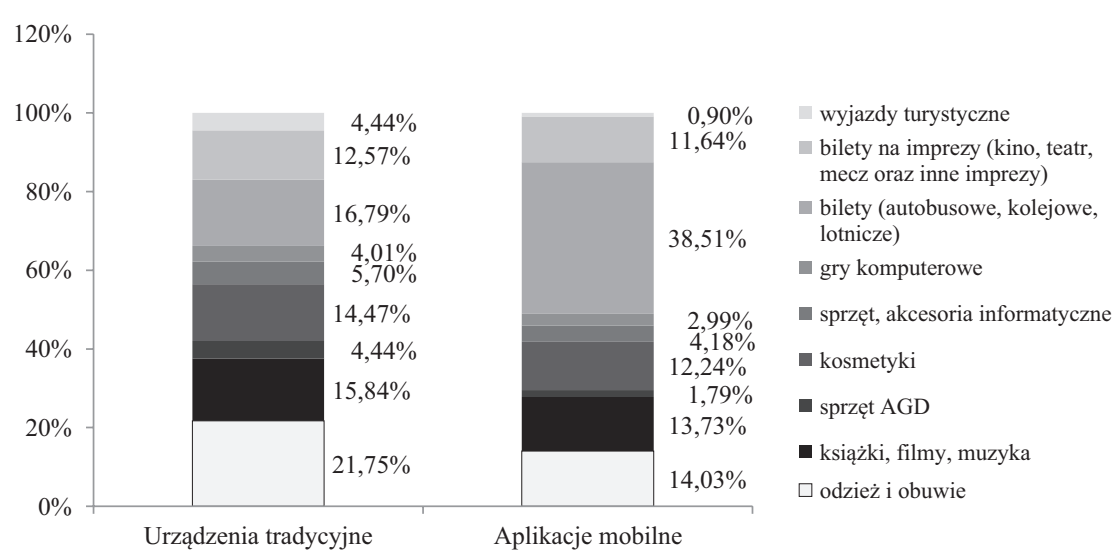

Rys. 5. Podstawowe rodzaje zakupów przez urządzenia mobilne i urządzenia tradycyjne

Źródło: opracowanie własne.

Nie mniej ciekawe okazały się wyniki odpowiedzi na pytanie o rodzaje produktów, których respondenci nigdy by nie kupili przez urządzenia mobilne i urządzenia tradycyjne. Średnio najwięcej ankietowanych (ponad 27\%) nigdy nie kupiłoby wyjazdów turystycznych (średnio 27\%), sprzętu AGD (średnio 22\%) oraz sprzętu komputerowego (14\%). W tym przypadku w zakupach przez aplikacje mobilne $37,31 \%$ ankietowanych nie kupiłoby wyjazdów turystycznych i sprzętu AGD $(21,49 \%)$, a w przypadku urządzeń tradycyjnych - sprzętu AGD (22,09\%) i wyjazdów turystycznych $(17,61 \%)$. W obu przypadkach wątpliwości budzi też zakup sprzętu i akcesoriów informatycznych. Najmniej osób miało wątpliwości co do zakupu w przypadku urządzeń mobilnych: książek, filmów, muzyki oraz biletów na imprezy, w przypadku urządzeń tradycyjnych - dokładnie tych samych produktów, co w przypadku urządzeń mobilnych (rys. 9).

W pytaniach o formy płatności wykorzystywane w handlu elektronicznym na obu rodzajach urządzeń wystąpiła wyjątkowo duża zgodność poglądów. Najczęściej wykorzystywanymi płatnościami są: przelew (średnio $47 \%$ odpowiedzi), płatność kartą (średnio 24\%) oraz formy gotówkowe (przedpłata, za pobraniem - średnio $22 \%$ ). Pieniądz elektroniczny stanowi tylko średnio $4,30 \%$ odpowiedzi. Średnio $2,38 \%$ respondentów pobiera tylko darmowe produkty (ponad trzy razy więcej na urządzenia mobilne), inne formy płatności stanowią ilości marginalne.

\section{Podsumowanie}

Przeprowadzone badania ankietowe, uzupełnione opiniami i komentarzami klientów handlu elektronicznego, prowadzą do następujących wniosków. Rośnie rola urządzeń mobilnych w społeczeństwie, z roku na rok coraz więcej osób posługuje 
się smartfonami i tabletami do komunikacji z internetem. Umacniająca się infrastruktura techniczna pozwala żywić nadzieję, że zostanie wykorzystana w handlu elektronicznym, tym niemniej zapowiadana „wymiana” handlu elektronicznego prowadzonego przy pomocy urządzeń tradycyjnych na prowadzony przy pomocy urządzeń mobilnych nie nastąpi tak szybko, jak to przepowiadano. Świadczy o tym przede wszystkim stwierdzenie respondentów, że w ciągu ostatnich trzech miesięcy podczas dokonywania zakupów w $91 \%$ wykorzystywali przeglądarkę internetową, a tylko w pozostałych $9 \%$ aplikację mobilną. Oczywiście trzeba wziąć pod uwagę, że w tych 91\% zakupów dokonywanych przez przeglądarkę internetową mieści się coraz więcej transakcji z wykorzystaniem smartfonu, chociaż - jak pokazują badania - nie we wszystkich dziedzinach.

Zjawiskiem, które może decydować o przewadze sprzedaży przez urządzenia mobilne, może się stać ich powszechna dostępność, o ile prawdziwe nie stanie się stwierdzenie, że „handel przez aplikacje mobilne jest domeną osób niepotrafiących posługiwać się komputerem".

Zastanawiająca jest beztroska klientów w kwestiach dotyczących bezpieczeństwa zakupów, zwłaszcza przez aplikacje mobilne (5\%). Jeszcze 15 lat temu była to kwestia najbardziej ograniczająca handel elektroniczny. Jednocześnie potrafią docenić zalety handlu przez przeglądarki internetowe, również tego, który jest prowadzony przez urządzenia tradycyjne: ,[...] możliwość skupienia się na transakcji i jej przemyślenia” oraz „[...] możliwość konsultacji z bliskimi”.

Istnieje świadomość innego sposobu wykorzystania przeglądarek internetowych na urządzeniach mobilnych i urządzeniach tradycyjnych. Wskazuje się np. na gorsze parametry urządzeń mobilnych w kwestii komunikacji biznesowej, a lepsze odczucia w stosunku do marketingu internetowego mniej zaśmiecającego urządzenia mobilne.

Wydaje się, że nie jest doceniona rola handlu elektronicznego prowadzonego w systemie przeglądarkowym dla inicjowania zakupów w tradycyjnym handlu bez użycia internetu. Jednak jest to wpływ trudny do oceny na podstawie wypowiedzi respondentów. Podkreślają oni większą rolę funkcji informacyjnych w systemach przeglądarkowych, ale trudno jest odseparować zakupy prowadzone dzięki temu $\mathrm{w}$ internecie od tych zainicjowanych $\mathrm{w}$ internecie, a zakończonych $\mathrm{w}$ rzeczywiście istniejących sklepach.

W przekroju branżowym urządzenia mobilne są wykorzystywane głównie do szybkich, bieżących operacji (jak np. zakup biletów komunikacyjnych), a w zakresie urządzeń tradycyjnych - zakupów przedmiotów materialnych (jak np. odzież i obuwie).

W każdym rodzaju handlu elektronicznego dominującymi metodami płatności są przelewy (46-48\%). Nadal mocna jest pozycja płatności kartowych i opartych na formach gotówkowych. Nie nastąpiło natomiast przewidywane zastąpienie tych ostatnich pieniądzem elektronicznym.

Bez względu na rodzaj handlu internetowego (przez aplikacje mobilne i przez system przeglądarek) i różnice pomiędzy nimi, znaczenie urządzeń mobilnych (z uwagi na ich powszechność, swoistą uniwersalność i względną łatwość obsługi) 
będzie rosło. Trudno jest przewidzieć, czy w najbliższym czasie smartfony, laptopy i wszystkie pozostałe urządzenia nie zostaną zastąpione zintegrowanymi urządzeniami posiadającymi własności zarówno jednej, jak i drugiej grupy urządzeń.

Dopóki to nie nastąpi, należy kontynuować badania nad wykorzystaniem urządzeń mobilnych w handlu elektronicznym, specyfikując dokładnie podobieństwa i różnice pomiędzy poszczególnymi rodzajami handlu elektronicznego, zarówno mobilnego, jak i de facto półmobilnego (laptopowego), oraz rozciągając je na środowisko pozawarszawskie.

\section{Bibliografia}

Batorski D., Korzystanie z mediów 2015. Warunki i jakość życia Polaków, [w:] J. Czapliński, T. Panek (red.), Social Diagnosis 2015. Objective and Subjective Quality of Life in Poland. Diagnoza społeczna 2015. Warunki i jakość życia Polaków, Warszawa 2015.

Chmielarz W., Study of Smartphones Usage from the Customer's Point of View, "Procedia Computer Science" 2015, Vol. 65, DOI: https://doi.org/10.1016/j.procs.2015.09.045.

Chmielarz W. (red.), Mobilne aspekty technologii Informacyjnych, Wydawnictwa Naukowe Wydziału Zarządzania UW, Warszawa 2016, DOI: https://doi.org/10.7172/978-83-65402-25-7.2016.wwz.7.

Chmielarz W., Łuczak K., Mobile Payment Systems in Poland-Analysis of Customer Preferences, "Transformations in Business \& Economics" 2016, Vol. 15(2a).

Chmielarz W., Parys T., Czynniki warunkujace wykorzystanie handlu elektronicznego w sklepach internetowych z punktu widzenia użytkowników indywidualnych, artykuł zgłoszony na XIV Kongres „Zarządzanie Wiedzą - Teoria i Praktyka”, Bydgoszcz 23-25 kwietnia 2017 r.

Handel mobilny w Polsce rośnie 3 razy szybciej niz e-commerce ogółem, 09.03.2015, http://nowymarketing.pl/a/5207,handel-mobilny-w-polsce-rosnie-3-razy-szybciej-niz-e-commerce-ogolem [dostęp: luty-marzec 2017].

Nielsen J., Mobile Website and Application Usability, Nielsen Norman Group Press 2013.

Number of digital shoppers in the United States from 2016 to 2021 (in millions), www.statista.com/statistics/183755/number-of-us-internet-shoppers-since-2009 [dostęp: luty 2017].

Parys T., Bariery zastosowania technologii mobilnych oraz ich ważność w ocenie użytkowników indywidualnych, [w:] B. Królikowska, M. Łatuszyńska (red.), Metody w badaniach naukowych. Wybrane problemy i zastosowania, Polskie Towarzystwo Informatyczne, Warszawa $2016 \mathrm{a}$.

Parys T., Identyfikacja barier zastosowania technologii mobilnych z perspektywy użytkowników indywidualnych, „Studia Ekonomiczne. Zeszyty Naukowe Uniwersytetu Ekonomicznego w Katowicach” 2016b, nr 281.

Parys T., Technologie mobilne - bariery zastosowań w ocenie użytkowników indywidualnych - wyniki badań 2016, „Studia Informatica Pomerania” 2016c, nr 3.

POLSKA.JEST.MOBI, 2015, www.tnsglobal.pl/coslychac/files/2015/05/POLSKA_JEST_MOBI_2015. pdf [dostęp: luty 2017].

Polski handel mobilny rozwija się szybciej niż e-commerce, 19.03.2015, https://marketingautomagic. pl/2015/03/polski-handel-mobilny-rozwija-sie-szybciej-niz-e-commerce [dostęp: marzec 2017].

Szewczyk Ł., Rynek smartfonów i tabletów osiaga dojrzałość. Spada popyt na urządzenia mobilne, 26.04.2016, https://media2.pl/telekomunikacja/133307-Rynek-smartfonow-i-tabletow-osiagadojrzalosc.-Spada-popyt-na-urzadzenia-mobilne.html [dostęp: marzec 2017].

Wielki J., Modele wplywu przestrzeni elektronicznej na organizacje gospodarcze, Wydawnictwo Uniwersytetu Ekonomicznego we Wrocławiu, Wrocław 2012. 
www.criteo.com/media/3748/criteo-state-of-mobile-commerce-q4-2015-ppt.pdf [dostęp: wrzesień 2016]. www.ons.gov.uk/businessindustryandtrade/retailindustry/bulletins/retailsales/aug2016 [dostęp: styczeń 2017].

Ziemba E. (red.), Technologie i systemy informatyczne w organizacjach gospodarki opartej na wiedzy, Wydawnictwo Wyższej Szkoły Bankowej w Poznaniu, Poznań 2008.

\section{The Use of Mobile Technologies in e-Commerce}

The aim of this article is the analysis of the possibilities of using in mobile commerce and mobile browsers on the mobile devices (smartphone, tablet) and traditional (laptop, desktop computer) from the customer's point of view. This analysis was carried out in two stages. The first stage assessed the possibilities and conditions for the use of mobile and traditional devices in e-commerce. In the second stage, electronic commerce conducted on mobile devices was compared with the use of mobile applications and web browsers, with electronic commerce carried out using browsers on traditional devices. The structure of the article consists of presenting the assumptions of the study, describing the methodology and the research sample as well as analyzing and discussing the obtained results. A qualitative study was conducted using the CAWI method on a selected sample of university students.

\section{Wykorzystanie technologii mobilnych w handlu elektronicznym}

Celem niniejszego artykułu jest analiza możliwości wykorzystania w handlu elektronicznym aplikacji mobilnych oraz przeglądarek internetowych na urządzeniach mobilnych (smartfon, tablet) $i$ tradycyjnych (laptop, komputer stacjonarny) z punktu widzenia klienta. Analizy tej dokonano dwustopniowo. W pierwszym etapie oceniono możliwości i uwarunkowania wykorzystania urządzeń mobilnych i tradycyjnych w handlu elektronicznym, a w drugim porównano handel elektroniczny prowadzony na urządzeniach mobilnych przy pomocy aplikacji mobilnych i przeglądarek internetowych $\mathrm{z}$ handlem elektronicznym dokonywanym za pomocą przeglądarek na urządzeniach tradycyjnych. Struktura artykułu składa się z przedstawienia założeń badania, opisu metodyki i próby badawczej oraz analizy i dyskusji uzyskanych wyników. Badanie mające charakter jakościowy przeprowadzono metodą CAWI na wyselekcjonowanej próbie studentów uczelni wyższych. 